\title{
A Histochemical Study of Developing Sporogenous Tissue and Periplasmodial Tapetum in the Anther of Parthenium (Compositae)
}

\author{
C. K. Rudramuniyappa \\ Department of Botany, Karnatak University, Dharwad-580 003, India
}

Accepted July 23, 1984

In the anther, the sporogenous tissue is the centre for all the happenings that occur concerning to meiosis and sporogenesis. These happenings, however, do not proceed without the assistance of tapetum. Therefore, the understanding of biochemical composition of these two tissues is very important. In the anther, the tapetum functions as a specialized nutritive tissue. Concerning to its nutritive/ transfer role, better picture could be obtained, if assessed histochemically, more so on the periplasmodial type, because of its very closeness with the microspores. The detailed histochemical, ultrastructural and physiological work on periplasmodium type of tapetum is very limited. In Tradescantia (Mapham and Lane 1969), the presence of polysaccharide bodies, lipids and proteins was reported. The autoradiographic and histochemical works on Rhoeo (Albertini and Souvre 1974), Lilium (Miki-Hirosige and Nakamura 1982) and on Helianthus (Vithanage and Knox 1979) have revealed its transfer role. In Lilium and Rhoeo (Williams and Heslop-Harrison 1979), uniform pattern of RNA synthesis in both secretory and plasmodium types was reported. In Helianthus (Nanda and Gupta 1981) the periplasmodium devoid of PAS positive starch storage. Thus the existing histochemical reports on plasmodium indicate that the detailed information on its visible storage nature as a whole is lacking. Although, some scanty reports on its transitory storage, particularly in the secretory type are available (Heslop-Harrison 1963, Panchaksharappa and Rudramuniyappa 1974, 1975). The purpose of the present study is to know the qualitative histochemical changes that occur in the sporogenous tissue and its derivatives, and in the periplasmodium tapetum at successive growth phases of their development. The substances chosen are: total polysaccharides, RNA, proteins and ascorbic acid (AA).

\section{Material and methods}

Different sizes of capitulum of Parthenium hysterophorus L. were collected and fixed in Carnoy's fluid $(3: 1)$ for about $3 \mathrm{hrs}$. The material was then processed by adopting standard microtechnique procedures of dehydration, paraffin infiltration and embedding. Microtome sections of $8 \mu \mathrm{m}$ thickness were used for the histochemical assessment. The following procedures were adopted: To localize insoluble polysaccharides, PAS; RNA, azure B (Jensen 1962); total proteins, mercuric bromophenol blue (Mazia et al. 1953); and ascorbic acid (AA), acidified silver nitrate 
$\left(\mathrm{AgNO}_{3}\right)$ method (Dave et al. 1968) were employed. The paraffin slides of AA were dried, deparaffinized and sealed by using DePeX. Appropriate controls of $10 \%$ cold perchloric acid for RNA (Kasten 1965), avoiding periodic acid in the PAS procedure (Cass and Jensen 1970) and 10\% formalin treatment prior to $\mathrm{AgNO}_{3}$ treatment for AA (Personal communication from Dr. C. K. Shah) were followed. Photomicrographs were obtained from 'Meopta' microscope and 'Mirax laborec' camera.

\section{Observations}

In the sporogenous tissue, the polysaccharides are feebly present (Figs. 1, 2) whereas RNA and protein contents are high both in the cytoplasm and in nucleoli (Fig. 3). AA content is also considerably rich in the sporogenous tissue (Fig. 4). When the sporogenous tissue undergoes differentiation, no visible change in its polysaccharide content is seen either in the meiocytes or in the microspore tetrads (Figs. 5,6 ). But the contents of RNA, proteins and AA decline in the late sporogenous tissue, and in the meiocytes the same concentrations persist in the cytoplasm (Figs. $7,8,9)$. The nucleoli generally retain higher basophilic character for RNA and proteins (Figs. 3. 7, 8). During meiosis, the additional PAS positive wall around the meiocytes and tetrads is not conspicuous (Figs. 5, 6). The microspores within the tetrads show reduced contents of RNA and proteins (Figs. 10, 11). Unlike RNA and proteins, the ascorbic acid content in the microspores of the tetrad exhibits variation among themselves (Fig. 12). In some, a little or no deposition of $\mathrm{AA}$ is seen and in others either one or two even three microspores accumulate abundant AA (Fig. 12). When the microspores are free from the tetrad, the feeble PAS stain continues to be present in them (Figs. 13, 14). As the microspores grow, RNA and protein contents increase in the cytoplasm (Figs. 16, 17, 18, 19), and their cell walls are distinctly PAS, azure B and protein positive, giving red purple, green and blue colours, respectively (Figs. 13, 14, 16, 17, 18, 19). Ascorbic acid content in the young microspores reduces to low level. At 2-celled pollen stage, the endexine of the pollen wall and three colpus regions react strongly purple with PAS (Fig. 15.) The presence of proteins is also noticed in the endexine (Fig. 20). In the mature pollen, the exine is spiny and reacts negative to PAS test, but gives deep green colour with azure B stain. Both vegetative and generative cells are high in RNA and protein contents, polysaccharide and AA contents are low in them (Figs. $15,20)$. In the premature pollen, PAS positive granules are seen and in the mature ones the cytoplasm becomes deeply PAS, RNA and protein positive. The AA content however remains low in the mature pollen.

The tapetum from the beginning of its differentiation, accumulates polysaccharide and AA granules (Figs. 2, 4). As it matures, both these substances increase and reach maximum during meiosis (Figs. 5,6,9). Parallely, the tissue also synthesizes high amounts of RNA and proteins which persist until it becomes peripalsmodium (Figs. 3, 7, 8, 10,11). At tetrad stage, the tapetum is still at its parietal position (Figs. 6, 10, 11). Following meiosis, the cell walls towards the theca gradually disorganize and results into gradual intrusion and mixing of the cytoplasmic contents (Figs. 13, 14, 16). The storage PAS positive and AA granules 

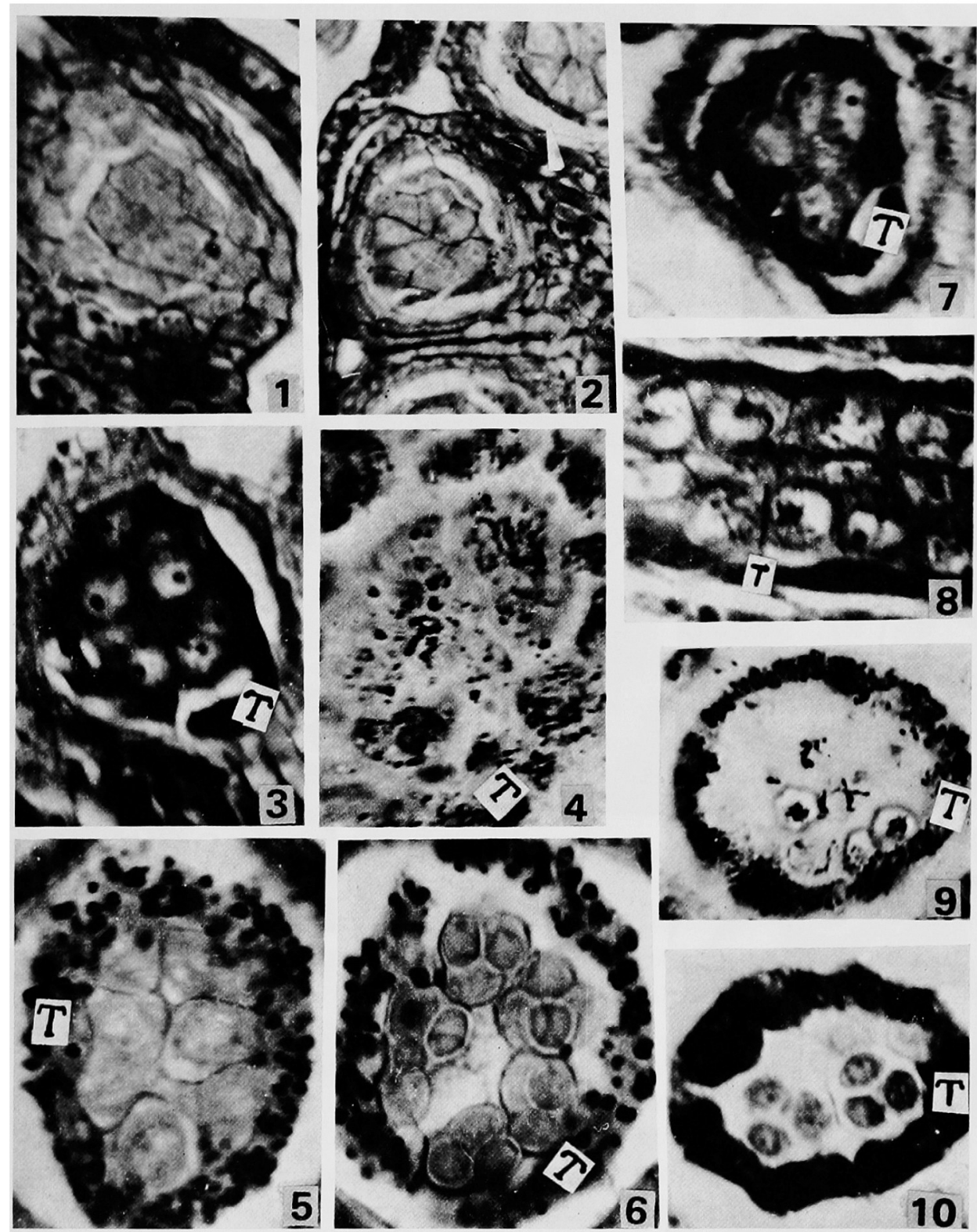

Figs. 1-10. Anther sections of Parthenium (T: tapetum). 1 and 2, sporogenous tissue shows feeble PAS stain in the cytoplasm. Note the beginning of PAS positive grains synthesis in the young tapetal cells (arrow). Fig. $1 \times 1500$. Fig. $2 \times 1000.3$, RNA in the sporogenous tissue is considerably reduced. Tapetum shows high RNA. $\times 1500$. 4, ascorbic acid is considerably rich in the sporogenous tissue and its deposition is high in the tapetum. $\times 1800$. 5, Meiocytes maintain feeble PAS stain. Note the abundant PAS positive grains in the tapetum. $\times 1500.6$, microspore tetrads show feeble PAS stain. Tapetum is high in PAS positive grains. $\times 1500$. 7, early meiocytes show reduced RNA content in their cytoplasm. Tapetum is high in RNA. $\times 1500$. 8, meiocytes at prophase show reduced protein content in their cytoplasm. Tapetum is high in proteins. $\times 1500$. 9, meiocytes show very low ascorbic acid content whereas tapetum stores high of it. $\times 1500$. 10, microspore tetrads show low RNA content. Tapetum shows high RNA content. 

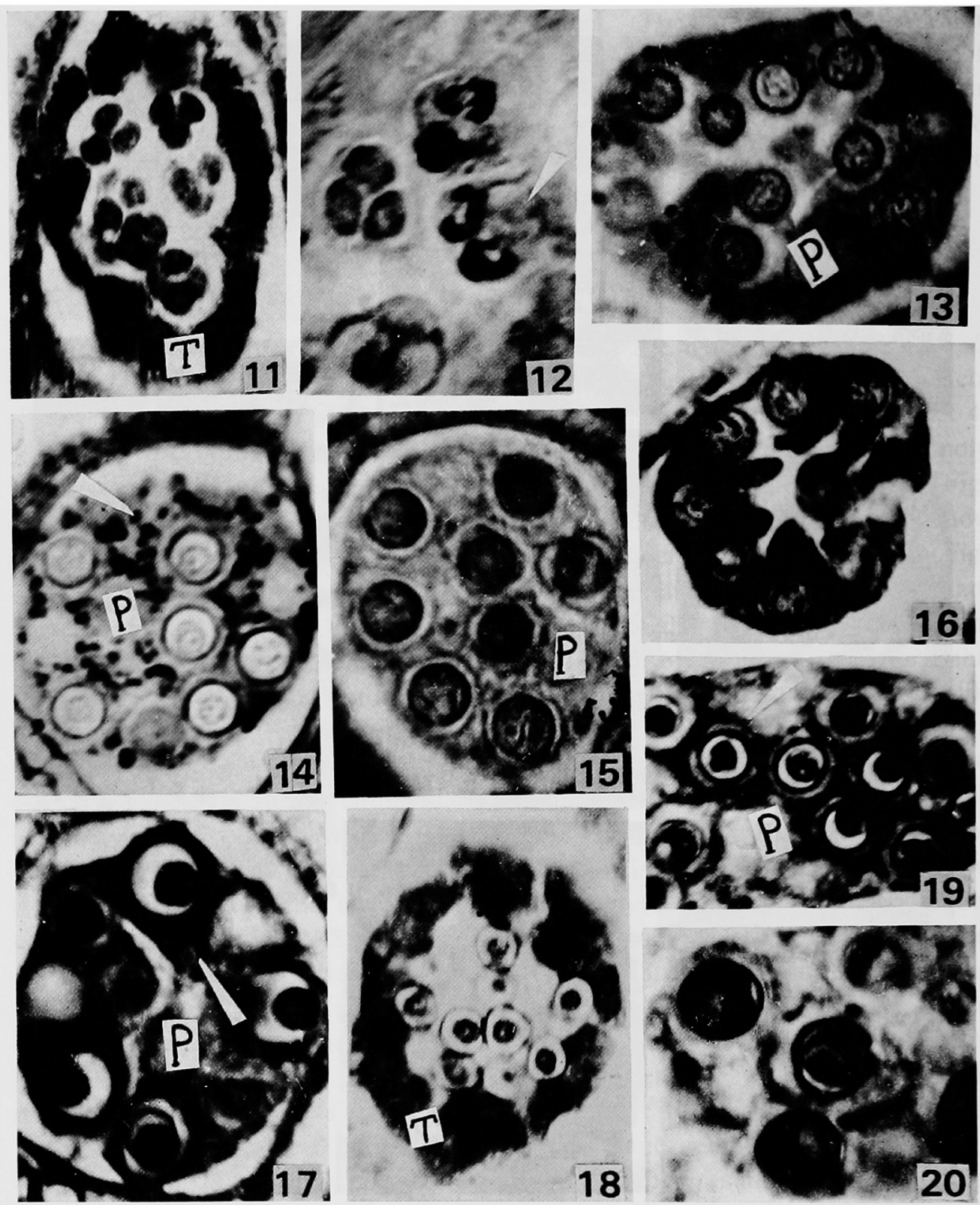

Figs. 11-20. Anther sections of Parthenium (T: tapetum; P: plasmodium). 11, microspore tetrads show low protein content. Tapetum maintains high protein content. $\times 1500.12$, note differential distribution of ascorbic acid with in the microspore tetrads. Some spores show high and others are devoid of AA (arrow). 13 and 14, the growing microspores show feeble PAS stain in the cytoplasm, but their cell walls are PAS positive. Note the gradual reduction of PAS positive grains in the tapetum in Fig. 13 and in Fig. 14 their concentration is more around the microspores (arrow). $\times 1500$. 15, tapetum at 2-celled pollen stage loses PAS positive grains $\times 1500$. 16, microspores show low RNA content. Tapetum is becoming plasmodium showing high RNA content. $\times 1300.17$, single celled pollen shows increase in RNA content. Note high RNA concentration around the pollwn (arrow). $\times 1500.18$, young microspores and tapetum show low protein content, respectively. $\times 1400$. 19 , single celled pollen shows increased protein content. Note protein concentration around the pollen (arrow). $\times 1500$. 20, Both vegetative and generative cells are high in protein content. Note reduction of proteins in the plasmodium. $\times 1800$. 
in it decline and in the periplasmodium they concentrate more around the growing microspores (Fig. 14) Similarly, RNA and proteins also decline in the ground cytoplasm of the plasmodium. But in the plasmodium these substances too concentrate more around the developing microspores (Figs. 17, 19). The periplasmodium now, engulfs all the microspores present in the anther locule. Between the microspores and the periplasmodium little space is left and is filled with azure B positive green tinge. The intensity of which increases, as the microspores grow, and when the exine is laid on them the green tinge vanishes. At 2-celled pollen stage, the storage PAS positive and AA granules disappear from the periplasmodium and only the feeble stain is left (Fig. 15). The periplasmodium gradually degenerates showing no storage, but possess, considerable amounts of RNA and proteins in it (Fig. 20).

\section{Discussion}

The nutritional role of the tapetum has been variously reviewed (Echlin 1971, Heslop-Harrison 1972). Apart from a few reports on its transitory storage nature (Heslop-Harrison 1963, Panchaksharappa and Rudramuniyappa 1974, 1975), the consistent occurrence of storage materials as observed in the present as well as in Kalanchoe (Rudramuniyappa and Annigeri 1984), however, has not been claimed so far. The tapetum Parthenium and Kalanchoe therefore, distinguishes from the rest of the taxa in showing abundant polysaccharide and AA granules from its inception unitl meiosis completes. From the nutritional point of view this kind of storage in the tapetum is very significant. Following meiosis, the storage in Parthenium gradually declines. This obviously suggests the utilization of storage or its metabolic products by the developing microspores. It has been generally known that the storage carbohydrates through hydrolysis release sugars which finally yield ATP. In the tapetum of Gerbera (Southworth 1971) labelled glucose and in Datura (Bhatia and Chopra 1978) abundant sugars were reported. In Tradescantia (Mapham and Lane 1969) the formation and degradation of polysaccharides to synthesize lipids was reported. The presence of RNA and proteins in abundance in the tapetum of Parthenium appears to play a significant biochemical/physiological role in the conversion and degradation of storage materials. Similarly, in Acacia (Kenrick and Knox 1979), Helianthus (Vithanage and Knox 1979) and in Rhoeo (Williams and Heslop-Harrison 1979) the presence of RNA and proteins was reported. Added to this, the activity of a few enzymes namely, esterase and acid phosphatase in Helianthus (Vithanage and Knox 1979) and esterase and ATPase in Datura (Hegde and Andrade 1982) has also been reported in the tapetum. Further, in Parthenium, both carbohydrates and AA appears to have a very close metabolic relationships in their synthesis as well as in degradation. With respect to the transfer role of the tapetum, the present study although does not provide direct evidence, but a few earlier studies have claimed unequivocally in support of its transfer role (HeslopHarrison 1972, Mascarenhas 1975, Miki-Hirosige and Nakamura 1982). To visualize such a transfer and/or nutritive role the periplasmodium type appears to be more convenient because of its closeness with the developing microspores. Here, 
surface to surface contact establishes and thereby systematic diffusion of the metabolic products could be greatly ensued from the tapetum. In Rhoeo (Albertini and Souvre 1974) nonhistone proetins were visualized, in Helianthus (Vithanage and Knox 1979) enzymes, esterase and acid phosphatase, and in Lilium (Miki-Hirosige and Nakamura 1982) the incorporation of myoinositol-2 ${ }^{3} \mathrm{H}$ labelled substances were found to be present on the pollen wall surface, strongly favours their tapetal origin and transfer. In the present study, however, only the green tinge is secreted by the periplasmodium and is seen diffusely around the microspores. Basically, this green substance and the pollen wall reacts uniformly with azure B. In conclusion, the periplasmodium in Parthenium is a dynamic and an organized tissue, meant to store and supply the basic raw materials to the developing pollen.

The sporogenous tissue is the central tissue for all the happenings that occur in the anther. This tissue from the beginning of its differentiation shows thin PAS positive cell walls and feeble PAS stain in the cytoplasm, and high contents of cytoplasmic and nucleolar RNA and proteins, but without storing starch. Similar observations have also been made in other plants (Rudramuniyappa and Panchaksharappa 1980, 1982, Rudramuniyappa and Annigeri 1985). However, the sporogenous tissue of Kalanchoe differs from the Parthenium and Triticum in showing no ascorbic acid content (Rudramuniyapoa and Annigeri 1984). This tissue in Euphorbia synthesizes abundant storage PAS positive grains. The synthesis of PAS positive grains in the sporogenous tissue of Euphorbia, is a distinct and a rare feature recorded so far. In Calanthe too, the presence of PAS positive grains was noticed in the sprogenous tissue (own observation). In Datura the activity of few enzymes was noticed in the sporogenous tissue (Hedgde and Andrade 1982). The sporogenous tissue in the anther is, therefore, metabolically/physiologically very active tissue.

In the meiocytes of Parthenium considerable reduction of RNA content is noticed. In other plants too similar reduction has been observed (Rudramuniyappa and Panchaksharappa 1982, Rudramuniyappa and Anniger 1985). But in Parthenium parallel to RNA, proteins and ascorbic acid contents were also reduce in the meiocytes. The reason(s) for such a general fall of cytoplsamic RNA and proteins in the meiocytes is yet to be understood properly. But the meiocytes of Kalanchoe have maintained rich ascorbic acid content (Rudramuniyappa and Annigeri 1984). It was shown that the reduction of RNA was related to the ribosomal breakdown and this was coincided with the peak activities of acid phosphatase and RNAse in Cosmos (Knox et al. 1971). With a low contents of RNA, proteins, ascorbic acid and without starch storage, the meiocytes of Parthenium enter the phase of meiosis and completes it also. The physiological dependency of the meiocytes on the tapetum is therefore imperative. It has been showed that in the absence of tapetum, meiocytes normally do not undergo meiosis (Heslop-Harrison 1963). This is a strong indication to show that the meiocytes depend on some specific external stimuli which induces them to undergo and/or to complete meiosis. The definite nature, source and cause of such stimuli, is yet to be exlpored. In Parthenium, the presence of storage in the tapetum might fulfills some of these requirements.

The pollen wall is unique, structurally and chemically. The first formed wall 
in Parthenium, is PAS positive and reacts green with azure B. It is also known that lignin reacts green with azure B (Jensen 1962). Similarly, the young spore wall in Lilium (Heslop-Harrison 1968) and in Acacia (Kenrick and Knox 1979) also reacts green. This green material is protosporopollenin, a sporopollenin precursor (HeslopHarrison 1971). Both lignin and sporopollenin are resistent to acetolysis and react with basic stains, azure B and toluidine blue (Southworth 1974). In view of these the accumulated green material around the microspores in Parthenium undoubtedly contains sporopollenin like materials. Added to this, the exine in Parthenium also reacts green with azure B. Hence, the origin of pollen wall materials from the periplasmodium tapetum is suggested.

\section{Summary}

Key words: Parthenium, Compositae, Anther, Histochemistry.

Total polysaccharides, RNA, proteins and ascorbic acid (AA) were localized histochemically in the developing sporogenous tissue and periplasmodium tapetum of Parthenium. Storage polysaccharides are not observed in the sporogenous tissue, meiocytes and in microspore tetrads. High contents of RNA and proteins present in the sporogenous tissue decline in the cytoplasm of the meiocytes. Young microspores show reduced contents of RNA and proteins which increase later when the microspores mature. The microspore wall, the exine and the diffused material accumulated around the microspores, all react green with azure B. AA content is rich in the sporogenous tissue, but it declines in the meiocytes. The microspores within the tetrad show varied quantity of AA. The tapetum exceptionally stores PAS positive and AA granules. RNA and proteins are also high in it. In the plasmodium the stored PAS positive and AA granules decline and lost whereas the RNA and proteins persist considerably in it. In the plasmodium all these histochemical constituents concentrate more around the microspores. The present study clearly recognized the storage nature of the periplasmodial tapetum.

\section{References}

Albertini, L and Souvre, A. 1974. Non-histone protein synthesis during microsporogenesis in Rhoeo discolor Hance. In: Fertilization in Higher Plants. Ed., Linskens, H.F., NorthHolland Pubs. Co., The Netherlands. pp. 49-56.

Bhatia, D. S. and Chopra, A. 1978. Histochemical localization of polysaccharides, phosphorylase $\alpha$-amylase in the developing anther of Datura alba Nees. In: Physiol. Sexual Repd. in Flowering Plants. Ed., Malik, C. P. et al., Kalyani Pubs. New Delhi. pp. 15-19.

Cass, D. D. and Jensen, W. A. 1970. Fertilization in barley. Am. J. Bot. 57: 62-72.

Dave, I. C., Saxena, O. P., Abraham, P. G. and Pandya, R. B. 1968 . Histochemical localization of $\alpha$-ascorbic acid in plants. J. Gujarat Univ. 11: 199-206.

Echlin, P. 1971. The role of the tapetum during microsporogenesis of angiosperms. In: Pollen, Development and Physiology. Ed., J. Heslop-Harrison. Butterworths, London. pp. 41-61.

Hegde, R. R. and Andrade, L. 1982. Anther development in Datura: Distribution of proteins, esterase and ATPase. Plant Science Letters 28: 95-101.

Heslop-Harrison, J. 1963. Ultrastructural aspects of differentiation in sporogenous tissue. Symp. Soc. Exptl. Biol. 17: 315-340.

- 1968. Wall development within the microspore tetrad of Lilium longiflorum. Can. J. Bot. 
46: 1185-1192.

- 1971. The pollen wall, structure and development. In: Pollen, Development and Physiology. Ed., Heslop-Harrison, J., Butterworths, London. pp. 75-98.

- 1972. Sexuality of angiosperms. In: Plant Physiology. Ed., Steward. F. C., Academic press, New York. 6C: 134-289.

Jensen, W. A. 1962. Botanical Histochemistry. Freeman, San Francisco.

Kasten, F. H. 1965. Loss of RNA and protein and changes in DNA during a 30-hours cold perchloric acid extraction of cultured cells. Stain Technol. 40: 127-135.

Kenrick, J. and Knox, R. B. 1979. Pollen development and cytochemistry in some Australian species of Acacia. Aust. J. Bot. 27: 413-427.

Knox, R. B., Dickinson, H. B. and Heslop-Harrison, J. 1971. Cytoplasmic RNA and enzyme activity during the meiotic prophase in Cosmos bipinnatus. In: Pollen, Development and Physiology. Ed., Heslop-Harrison, J., Butterworths, London. pp. 32-35.

Mapham, R. H. and Lane, G. R. 1969 . Formation and development of the tapetal periplasmodium in Tradescantia bracteata. Protoplasma 68: 175-192.

Mascarenhas, J. P. 1975. The biochemistry of angiosperm pollen development. Bot. Rev. 41 : 259-314.

Mazia, D., Brewer, P. A. and Alfert, M. 1953. The cytochemical staining and measurement of proteins with mercuric bromophenol blue. Biol. Bullt. 104: 57-67.

Miki-Hirosige, H. and Nakamura, S. 1982. Incorporation of label from myoinositol-2 ${ }^{3} \mathbf{H}$ by young anther of Lilium longiflorum. Phytomorphology 33: 85-94.

Nanda, K. and Gupta, S. C. 1981. Histochemical localization of total carbohydrates of insoluble polysaccharides in Helianthus anthers. J. Indian Bot. Soc. 60: 257-260.

Panchaksharappa, M. G. and Rudramuniyappa, C. K. 1972. Localization of nucleic acids and insoluble polysaccharides in the anther of Zea mays L.-A histochemical study. Cytologia 39: $153-169$.

- and - 1975. Localization of polysaccharides in the anthers of Sorghum vulgare Pers. and Paspalum scrobiculatum L. J. Karnatak Univ. Sci. 20: 124-129.

Rudramuniyappa, C. K. and Panchaksharappa, M. G. 1980. Pollen development in Triticum durum Desf.-A histochemical study. J. S. Afr. Bot. 46: 33-43.

- and - 1982. Histochemistry of anther in Pennisetum and Setaria. Beitr. Biol. Pflanzen. 57: 193-203.

- and Annigeri, B. G. 1984. A histoshemical study of meiocytes, microspores, pollen and the tapetum in Kalanchoe. Nord. Jour. Bot. 4: 661-667.

- and - 1985. Histochemical observations on the sporogenous tissue and tapetum in the anther of Euphorbia. Cytologia 50: 39-48.

Southworth, D. 1971. Incorporation of radioactive precursors into the developing pollen walls. In: Pollen, Development and Physiology. Ed. Heslop-Harrison, J., Butterworths, London. pp. 115-124.

- 1974. Solubility of pollen exines. Am. J. Bot, 61: 36-44.

Vithanage, H. I. M. V. and Knox, R. B. 1979. Pollen development and quantitative cytochemistry of exine and intine enzymes in sunflower, Helianthus annuus L. Ann. Bot. 44: 95-106.

Williams, E. G. and Heslop-Harrison, J. 1979. A comparison of RNA synthetic activity in the plasmodial and secretory types of tapetum during the meiotic interval. Phytomorphology 29: $370-381$. 